\title{
Validasi Metode Penentuan Sitronelal dalam Minyak Atsiri Sereh Wangi secara Kromatografi Gas
}

\author{
Yorfan Ruwindya \\ DIII Analisis Kimia, Jurusan Kimia, Fakultas Matematika dan Ilmu Pengetahuan Alam Universitas Islam Indonesia \\ Jl. Kaliurang Km 14,5, Sleman, Yogyakarta, 55584 \\ corresponding author : 186102501@uii.ac.id \\ DOI : 10.20885/ijca.vol3 .iss2.art2
}

\section{ARTIKEL INFO}

Diterima : 12 Juli 2020

Direvisi : 20 Agustus 2020

Diterbitkan : 09 September 2020

Kata kunci : Minyak Sereh wangi,

Validasi Metode, Linieritas, Akurasi,

Presisi, LOD, LOQ

\begin{abstract}
ABSTRAK
Sitronelal merupakan salah satu komponen utama yang terdapat dalam minyak sereh wangi. Kadar sitronelal yang terdapat dalam minyak sereh wangi sangat penting untuk diketahui, karena menentukan kualitas dari minyak sereh wangi tersebut. Penentuan kandungan sitronelal dalam minyak sereh wangi salah satunya dapat menggunakan metode kromatografi gas seperti yang akan dilakukan pada penelitian ini. Metode ini merupakan salah satu metode yang dikembangkan berdasarkan penelitian yang sudah dilakukan sebelumnya sehingga perlu dilakukan validasi metode. Kandungan sitronelal yang terdapat pada sampel minyak atsiri sereh wangi sebesar $60,610 \%$ sampai $60,655 \%$. Hasil validasi metode yaitu nilai linieritas diperoleh sebesar 0,999 , nilai persen relatif standar deviasi (\%RSD) sebesar $0,0360 \%$, nilai persen perolehan kembali (\% recovery) sebesar $92,628 \%$, serta nilai batas deteksi (LOD) sebesar 1,971\% dan nilai batas kuantitatif (LOQ) sebesar $6,570 \%$. Hasil validasi metode penentuan sitronelal pada minyak sereh wangi secara kromatografi gas menyatakan bahwa metode dapat digunakan pada kromatografi gas karena semua parameter validasi yang telah di lakukan memenuhi persyaratan.
\end{abstract}

\begin{tabular}{ll}
\hline ARTICLE INFO & ABSTRACT \\
\hline Received : 12 July 2020 & Citronellal is one of the main components found in citronella oil. \\
Revised : 20 August 2020 & Citronellal content contained in citronella oil is very important to \\
Published : O9 September 2020 & know because it determines the quality of the citronella oil. One of \\
Keywords : Citronella oil, Validation & the ways to determine citronellal content in fragrant lemongrass \\
method, Linearity, Accuracy, & oil is the gas chromatography method as will be done in this study. \\
Precision, LOD, LOQ & This method is one of the methods developed based on research \\
& that has been done before, so it is necessary to validate the method. \\
& The content of citronellal contained in the citronella essential oil \\
& sample is $60.610 \%$ to $60.655 \%$. The results of the validation of the \\
& method were the linearity value obtained at 0.999, the percent \\
& relative standard deviation (\% RSD) of 0.0360\%, the percent \\
& recovery value (\% recovery) of $92.628 \%$ and the detection limit \\
& value (LOD) of $1.971 \%$ and the limit value. quantitative (LOQ) of \\
& $6.570 \%$. The validation results of the citronellal determination \\
& method on citronella oil by gas chromatography state that the \\
& method can be used in gas chromatography because all the \\
& validation parameters that have been carried out agree with the \\
& requirements.
\end{tabular}




\section{PENDAHULUAN}

Sereh wangi merupakan salah satu tanaman rempah yang biasa digunakan dalam masakan sebagai bumbu dapur dan obat-obatan yang memiliki kahsiat, salah satunya sebagai zat anti nyamuk [1]. Budidaya sereh wangi di Indonesia belum banyak dilakukan, hal ini dikarenakan sebagian besar hanya digunakan untuk kebutuhan sehari-hari sebagai campuran dalam masakan. Namun bila tanaman ini diolah menjadi minyak atsiri, maka tanaman ini akan memberikan nilai ekonomi yang lebih tinggi.Sitronelal, sitronelol, dan graniol merupakan komponen kimia utama dari minyak sereh wangi. Komponen senyawa tersebut membuat minyak sereh wangi memiliki bau yang khas citrus. Komponen lain dari minyak sereh wangi dapat berupa golongan alkohol, hidrokarbon, ester, aldehid, keton, oksida, lactone, dan terpen [2]. Jenis hidrokarbon yang terkandung dalam minyak atsiri sereh wangi yang utama terdiri dari persenyawaan terpene, parafin, olefin, dan hidrokarbon aromatik dan oxygenated hydrocarbon yang seperti yang ditunjukkan pada Gambar 1 [3].

Standar pasar internasional mensyaratkan minyak sereh wangi harus memiliki kandungan sitronelal lebih dari 35\% [4]. Kandungan sitronelal yang tinggi merupakan salah satu indikator untuk menentukan kualitas dari minyak sereh wangi yang baik, di samping analisis fisik meliputi warna, berat jenis, dan indeks bias. Pengujian kandungan sitronelal dapat dilakukan dengan menggunakan metode kromatografi gas. Hal ini dikarenakan minyak atsiri juga dikenal sebagai minyak eteris atau minyak terbang sehingga mudah menguap pada suhu kamar tetapi tidak mengalami dekomposisi [1]. Sifat ini sesuai dengan salah satu syarat suatu sampel dapat dianalisis dengan menggunakan kromatografi gas yaitu mudah menguap [5].<smiles>CC(C)=CCCC(C)CC=O</smiles>

\section{Gambar 1. Struktur sitronelal}

Metode yang digunakan untuk menentukan kandungan sitronelal dalam minyak sereh wangi adalah metode yang diperoleh dari penelitian sebelumnya [6]. Penelitian sebelumnya telah didapatkan kondisi optimum kromatografi gas untuk analisis minyak sereh wangi, yaitu pada pengaturan split $159 \mathrm{~mL} / \mathrm{min}$ dengan kenaikan suhu oven sebesar $2^{\circ} \mathrm{C}$. Penjaminan terhadap kualitas produk sangat penting terhadap suatu produk, tidak terkecuali minyak atsiri sereh wangi.

Penentuan kandungan sitronelal, yang merupakan kandungan utama dari minyak sereh wangi menjadi penting dilakukan. Dalam penelitian yang dilakukan, metode yang digunakan tersebut belum menjadi metode yang baku karena merupakan sebuah metode pengembang sehingga perlu dilakukan validasi terhadap metode tersebut. Validasi metode merupakan suatu proses untuk membuktikan bahwa suatu metode analisis dapat digunakan sesuai dengan parameter tertentu [7]. Metode yang sudah tervalidasi akan membantu memberikan jaminan terhadap hasil analisis dan dapat dipercaya [8]. Oleh karena itu, pada penelitian ini dilakukan validasi terhadap metode analisis kandungan sitronelal dalam minyak sereh wangi secara kromatografi gas. Parameter validasi yang digunakan sebagai acuan meliputi linieritas, batas deteksi, akurasi, dan presisi. Penelitian ini merupakan salah satu upaya dalam hal pengembangan minyak atsiri melalui metode analisis yang digunakan.

\section{METODE}

\subsection{Alat}

Peralatan yang digunakan pada penelitian ini antara lain Instrumen Kromatografi Gas Thermo Scientific Trace 1300, Syringe, dan seperangkat alat gelas. 


\subsection{Bahan}

Bahan yang digunakan pada penelitian ini adalah sampel minyak atsiri sereh wangi yang berasal dari perkebunan di Yogyakarta, etanol pro kromatografi, standar sitronelal, dan kertas saring.

\subsection{Prosedur Kerja}

\subsubsection{Kondisi Kromatografi Gas}

Kromatografi gas di atur dengan pengaturan sistem injeksi yaitu suhu injektor $250^{\circ} \mathrm{C}$, suhu detektor $250^{\circ} \mathrm{C}$, suhu awal oven $80^{\circ} \mathrm{C}$ dan suhu akhir oven $120^{\circ} \mathrm{C}$ dengan kenaikan suhu sebesar $2^{\circ} \mathrm{C} / \mathrm{menit}$, serta laju alir gas pembawa $1 \mathrm{~mL}$.menit dengan split $159 \mathrm{~mL} / \mathrm{menit}$.

\subsubsection{Persiapan Sampel}

Sampel minyak yang diperoleh dari hasil pembelian disaring menggunakan kertas saring sehingga diperoleh sampel minyak yang bebas dari pengotor.

\subsubsection{Pembuatan Deret Larutan Standar Sitronelal}

Standar sitronelal diambil sebanyak $1 ; 2 ; 3$; 4; dan $5 \mathrm{~mL}$ dan dimasukkan ke labu $10 \mathrm{~mL}$. Larutan diencerkan dengan etanol sampai tanda batas dan dihomogenkan. Larutan standar sitronelal diambil sebanyak $1 \mu \mathrm{L}$ kemudian diinjeksikan ke dalam sistem kromatografi gas.

\subsubsection{Penentuan Konsentrasi Sitronelal}

Minyak atsiri sebanyak $2 \mathrm{~mL}$ dimasukkan dalam labu ukur $10 \mathrm{~mL}$ dan di encerkan menggunakan etanol sampai tanda batas. Minyak atsiri yang sudah diencerkan diambil sebanyak 1 $\mu \mathrm{L}$ kemudian diinjeksikan ke dalam sistem kromatografi gas. Luas area yang diperoleh kemudian digunakan untuk menentukan konsentrasi sitronelal dalam sampel.

\subsubsection{Penentuan Presisi}

Minyak atsiri sebanyak $2 \mathrm{~mL}$ dimasukkan dalam labu ukur $10 \mathrm{~mL}$ dan di encerkan menggunakan etanol sampai tanda batas. Minyak atsiri yang sudah diencerkan diambil sebanyak 1 $\mu \mathrm{L}$ kemudian diinjeksikan ke dalam sistem kromatografi gas dan dilakukan pembacaan sebanyak 5 kali. Presisi ditentukan dengan menghitung nilai presentase relatif standar deviasi (\%RSD). Penentuan nilai presisi ditentukan dengan menghitung nilai simpangan baku (SD) dan dari nilai simpangan baku dapat dihitung nilai simpangan baku relatif(RSD), menggunakan Persamaan 1.

$$
\begin{aligned}
& \mathrm{SD}=\sqrt{\frac{\sum_{\mathrm{i}=1}^{\mathrm{n}}\left(\mathrm{X}_{\mathrm{i}}-\overline{\mathrm{X}}\right)^{2}}{\mathrm{n}-1}} \\
& \operatorname{RSD}(\%)=\frac{\mathrm{SD}}{\mathrm{x}} \times 100 \% .
\end{aligned}
$$

$$
\begin{aligned}
\text { dimana } \mathrm{SD} & =\text { standar deviasi } \\
\mathrm{RSD} & =\text { simpangan baku relatif } \\
\mathrm{Xi} & =\text { nilai dari masing-masing pengukuran } \\
\overline{\mathrm{X}} & =\text { nilai rata-rata pengukuran } \\
\mathrm{N} & =\text { jumlah pengukuran (pengulangan) }
\end{aligned}
$$

\subsubsection{Penentuan Akurasi}

Minyak atsiri sebanyak $2 \mathrm{~mL}$ dimasukkan dalam labu ukur $10 \mathrm{~mL}$ dan di encerkan menggunakan etanol sampai tanda batas. Minyak atsiri yang sudah diencerkan diambil sebanyak 1 $\mu \mathrm{L}$ kemudian diinjeksikan ke dalam sistem kromatografi gas. Luas area yang diperoleh kemudian digunakan untuk menentukan konsentrasi sitronelal dalam sampel. Penentuan nilai akurasi ditentukan dengan menggunakan Persamaan 2.

$\%$ Perolehan kembali (recovery) $=\frac{(\mathrm{C} 1-\mathrm{C} 2)}{\mathrm{C} 3} \times 100 \%$

dimana $\mathrm{C} 1=$ konsentrasi dari analit dalam contoh + standar 
$\mathrm{C} 2=$ konsentrasi dari analit dalam contoh

C3 = konsentrasi standar yang ditambahkan

\section{HASIL PENELITIAN}

Penentuan kanduangan sitronelal dalam sampel minyak atsiri sereh wangi menggunakan metode kromatografi gas. Penentuan ini didasarkan pada metode kurva kalibrasi. Metode ini dilakukan dengan membandingkan suatu zat dalam suatu sampel yang tidak diketahui konsentrasinya kedalam sampel standar yang konsentrasinya telah diketahui. Larutan standar sitronelal yang sudah diketahui konsentrasinya yaitu $0 \%, 10 \%, 20 \%, 30 \%, 40 \%$, dan $50 \%$. Larutan standar kemudian di injeksikan ke dalam sistem kromatografi gas. Hasil yang diperoleh berupa data luas area dari setiap konsentrasi larutan standar yang bisa dilihat pada Tabel 1 .

TABEL I. Luas area larutan standar sitronelal

\begin{tabular}{cc}
\hline Konsentrasi (\%) & Luas Area \\
\hline 0 & 0,000 \\
10 & 125,650 \\
20 & 239,811 \\
30 & 382,260 \\
40 & 514,806 \\
50 & 626,715 \\
\hline
\end{tabular}

Data yang diperoleh dari Tabel I digunakan untuk membuat kurva kalibrasi antara konsentrasi larutan standar sitronelal dengan luas area yang digambarkan melalui grafik pada Gambar 2.

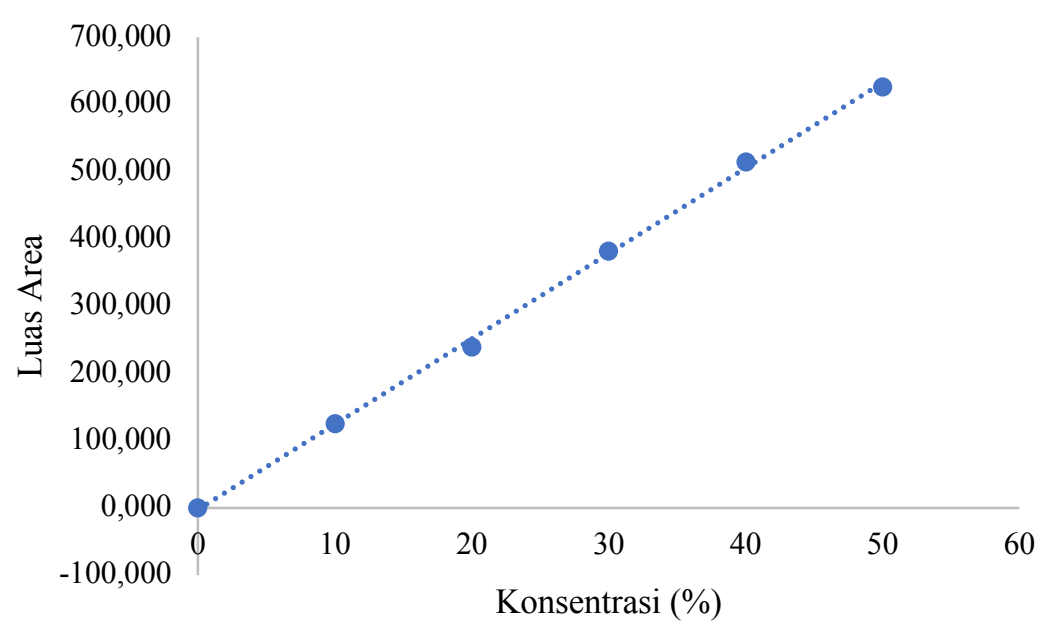

Gambar 2. Linieritas larutan standar sitronelal

Kurva kalibrasi standar sitronelal yang menunjukkan hubungan luas area berbanding lurus dengan konsentrasi. Artinya semakin besar nilai konsentrasi larutan standar maka semakin besar pula nilai luas areanya. Persamaan regresi linear yang diperoleh yaitu, $y=12,696 x-2,5186$ dengan koefisien determinasi $\mathrm{R}^{\wedge} 2=0,999$. Nilai determinasi yang diperoleh menandakan sudah sesuai standar karena melebihi nilai minimal yaitu 0,995 [9]. Kandungan sitronelal dalam sampel minyak atsiri sereh wangi ditentukan dengan menginjeksikan sampel ke dalam sistem kromatografi gas. Kadar sitronelal yang terdapat dalam sampel, dapat dilihat pada Tabel 2. 
TABEL II. Kadar sitronelal dalam sampel

\begin{tabular}{ccc}
\hline Sampel & Luas Area & Konsentrasi (\%) \\
\hline Sampel 1 & 151,487 & 60,651 \\
Sampel 2 & 151,497 & 60,655 \\
Sampel 3 & 151,472 & 60,645 \\
Sampel 4 & 151,388 & 60,612 \\
Sampel 5 & 151,383 & 60,610 \\
\hline & Rata-rata & 60,635 \\
\hline
\end{tabular}

Kandungan sitronelal dalam sampel minyak sereh wangi berkisar antara 60,610\% sampai $60,655 \%$ dengan rata-rata $60,635 \%$. Data yang diperoleh menunjukkan bahwa kandungan sitronelal dalam sampel minyak sereh wangi sesuai dengan kandungan minimal sitronelal yang dipersyaratkan oleh Standar Nasional Indonesia SNI 06-3953-1995 BSN tentang minyak serai yaitu sebesar $35 \%$. Metode kemudian di validasi dengan parameter presisi, akurasi, linieritas, serta LOD dan LOQ. Nilai presisi metode penentuan sitronelal secara kromatografi gas ini ditentukan menggunakan metode uji ketahanan (repeatability). Presisi dalam metode ini diukur sebagai simpangan baku atau simpangan baku relatif (koefisien variasi). Data hasil perhitungan nilai presisi dapat dilihat pada Tabel 3.

TABEL III. Hasil penentuan presisi

\begin{tabular}{cc}
\hline Preparasi & Konsentrasi (\%) \\
\hline 1 & 60,651 \\
2 & 60,655 \\
3 & 60,645 \\
4 & 60,612 \\
5 & 60,610 \\
\hline Rata-rata & 60,635 \\
\hline SD & 0,022 \\
\hline \% RSD & 0,036 \\
\hline
\end{tabular}

Hasil nilai \%RSD menunjukkan presisi metode yang digunakan untuk penentuan sitronelal dalam sampel minyak sereh wangi diterima, hal ini dikarenakan nilai tersebut kurang dari 2\% [8].

Nilai tersebut diperoleh dengan menggunakan metode adisi yaitu penambahan sejumlah larutan standar ke dalam sampel atau dikenal dengan spiking. Selisih nilai hasil antara kandungan larutan yang di-spike dengan kandungan sampel tanpa spike dilakukan perbandingan dengan kadar yang sebenarnya. Hasil penentuan persen perolehan kembali (recovery) pada penentuan sitronelal dalam minyak atsiri sereh wangi dapat dilihat pada Tabel 4.

TABEL IV. Hasil penentuan akurasi

\begin{tabular}{cccc}
\hline $\begin{array}{c}\text { Konsentrasi sampel non } \\
\text { spike, B (mg/L) }\end{array}$ & $\begin{array}{c}\text { Konsentrasi sampel } \\
\text { spike, A (mg/L) }\end{array}$ & $\begin{array}{c}\text { Konsentrasi } \\
\text { target, C (mg/L) }\end{array}$ & \% Recovery \\
\hline 4,620 & 13,420 & 9,5 & 92,628 \\
\hline
\end{tabular}

Hasil yang diperoleh menunjukkan bahwa akurasi dari metode yang digunakan dalam analisis penentuan sitronelal dalam sampel minyak sereh wangi ini baik karena berada pada rentang yang ditetapkan. Rentang nilai persen perolehan kembali (\% recovery) yang baik berada pada nilai 80 $110 \%$ [9]. Nilai batas deteksi dan batas kuantitatif diperoleh dari data hasil pengukuran kurva kalibrasi linear dengan menghitung nilai larutan standar sitronelal. Hasil dari pengukuran larutan standar kemudian digunakan untuk mennentukan nilai batas deteksi dan batas kuantitatif. Batas deteksi dan batas kuantitatif dihitung berdasarkan pada standar deviasi (SD) respon dan kemiringan (slope) linieritas baku. Hasil penentuan nilai batas deteksi (LOD) dan batas kuantitatif (LOQ) dapat dilihat pada Tabel 5 . 
TABEL V. Nilai LOD dan LOQ

\begin{tabular}{cc}
\hline Parameter & Nilai \\
\hline Slope & 12,696 \\
Standar Deviasi (SD) & 8,341 \\
LOD & $1,971 \%$ \\
LOQ & $6,570 \%$ \\
\hline
\end{tabular}

Berdasarkan hasil validasi yang diperoleh dari setiap parameter yang digunakan, dapat dikatakan bahwa metode penentuan sitronelal dalam minyak sereh wangi secara kromatografi gas bisa digunakan karena semua hasil parameter validasi yang dilakukan memenuhi persyaratan.

\section{KESIMPULAN}

Berdasarkan penelitian, dapat disimpulkan bahwa metode penentuan sitronelal dalam minyak sereh wangi secara kromatografi gas bisa digunakan sesuai peruntukkannya karena semua hasil parameter validasi yang dilakukan memenuhi persyaratan, dengan nilai linieritas sebesar 0,999; nilai persen relatif standar deviasi (\%RSD) sebesar $0,0360 \%$; nilai persen perolehan kembali ( $\%$ recovery) sebesar 92,628\%; serta nilai batas deteksi (LOD) yang sebesar 1,971\% dan nilai batas kuantitatif (LOQ) sebesar 6,570\%.

\section{Acknowledgment}

Terimakasih kepada Direktorat Penelitian dan Pengabdian Masyarakat (DPPM) Universitas Islam Indonesia atas bantuan dana hibah pada penelitian ini melalui skema penelitian Laboran tahun 2020.

\section{Daftar Pustaka}

[1] Yulvianti, M., Sari, R. M., \& Amaliah, E. F., "Pengaruh Perbandinagn Campuran Pelarut N-HeksanaEtanol Terhadap Kandungan Sitronelal Hasil Ekstraksi Sereh Wangi (Cymbopogon nardus)", Jurnal Integrasi Proses, Vol. 5, No. 1, 8-14, 2014.

[2] Sulaswatty, A., dan Adilina, I. B., "Quo Vadis Minyak Serai Wangi dan Produk Turunannya", Jakarta: LIPI Press, 2019.

[3] Harianingsih, Wulandari, R., Harliyanto, C., \& Andiani, C. N., "Identifikasi GC-MS Ekstrak Minyak Atsiri dari Sereh Wangi (Cymbopogon winterianus) Menggunakan Pelarut Metanol", Techno, ISSN 1410 - 8607, Volume 18 No. 1, 023 - 027, 2017.

[4] Sastrohamidjojo, H., "Kimia Minyak Atsiri”, Yogyakarta: FMIPA, Universitas Gadjah Mada, 2002.

[5] Rizalina, H., Cahyono, E., Mursiti, S., Nurcahyo, B., \& Supartono, "Optimasi Penentuan Kadar Metanol dalam Darah Menggunakan Gas Chromatography", Indonesian Journal of Chemical Science, 7 (3), 2018.

[6] Ruwindya, Y., "Optimasi Metode Analisis Minyak Atsiri Sereh Wangi Secara Kromatografi Gas", Indonesian Journal of Chemical Analysis, Vol. 02, Hal. 54-59, 2019.

[7] Kuntari, Aprianto, T., Baruji, \& Noor, R. H., "Validasi Metode Penentuan Amonium Klorida dalam Obat Batuk Hitam secara Titrimetri", Indonesian Journal of Chemical Analysis, Vol. 01, No. 1, Hal. 35 - 41, 2018.

[8] Riyanto, "Validasi \& Verifikasi Metode Uji: Sesuai dengan ISO/IEC 17025 Laboratorium Pengujian dan Kalibrasi", Edisi 1, Yogyakarta: Deepublish, 2014.

[9] AOAC International, "Official Methods of Analysis of AOAC International”, AOAC Official Methods of Analysis, 1 - 17, 2016.

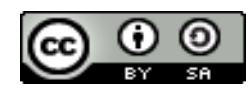

Jurnal IJCA is licensed under aÂ Creative Commons Attribution ShareAlike 4.0 